Technical note

\title{
Soil management and planting spacing effects on establishment of mixed swards of purple stargrass (Cynodon nlemfuensis cv. BRS Lua) and forage peanut (Arachis pintoi cv. Belmonte) in an area of degraded Brachiaria brizantha
}

Divaney Mamédio ${ }^{\text {ac* }}$

Carlos Maurício Soares de Andrade ${ }^{b}$

Aliedson Ferreira Sampaio ${ }^{b}$

Daniele Rebouças Santana Loures ${ }^{c}$

${ }^{a}$ Universidade Estadual de Maringá .Pós-Graduação em Zootecnia, Departamento de Zootecnia, Maringá, Paraná, Brasil.

${ }^{\mathrm{b}}$ Embrapa Acre, Rio Branco, Acre, Brasil.

${ }^{\mathrm{c}}$ Universidade Federal do Recôncavo da Bahia .Centro de Ciências Agrárias, Ambientais e Biológicas, Cruz das Almas, Bahia, Brasil.

* Corresponding author: divaney.zootecnia@gmail.com

\begin{abstract}
:
The aim of this study was to assess the effect of soil management and planting spacing on establishment performance of mixed swards of purple stargrass (Cynodon nlemfuensis $\mathrm{cv}$. BRS Lua) and forage peanut (Arachis pintoi cv. Belmonte). The treatments comprised two methods of soil management (conventional tillage, with desiccation followed by harrowing; and no-tillage, with sequential desiccation with glyphosate) and two planting spacing (50 and $100 \mathrm{~cm}$ between rows). The experimental design was in randomized blocks, arranged in split-plot. Both methods of soil management ensured rapid pasture establishment, with canopy cover greater than $94 \%$ at $84 \mathrm{~d}$ after planting, with the notillage surpassing the conventional tillage, and at a cost of no-tillage $7 \%$ lower. Reducing planting spacing from $100 \mathrm{~cm}$ to $50 \mathrm{~cm}$ accelerated canopy cover and reduced weed incidence. The initial contribution of forage peanut in the botanical composition was
\end{abstract}


relatively small, declining by $3.8 \%$ on average at $36 \mathrm{~d}$ after planting to less than $1.2 \%$ at $84 \mathrm{~d}$. No-tillage was as efficient in establishing mixed swards as conventional tillage.

Key words: Arachis pintoi, Cynodon nlemfuensis, No-tillage, Stolon planting, Pasture renovation.

Received:28/07/2018

Accepted: 10/12/2018

The heterogeneity of climate, soil and livestock production systems in Brazil requires greater diversification of planted pastures to reduce the vulnerability of the livestock sector and promote a better genotype-environment adequacy ${ }^{(1)}$. The clearest example of this vulnerability is the degradation of millions of hectares of planted pastures with Brachiaria brizantha cv. Marandu due to soil waterlogging in the Brazilian Amazon ${ }^{(2)}$.

Several cultivars of Cynodon grasses have been researched since the decade of $60^{(3)}$ showing high productivity and persistence in different regions of Brazil. However, the adoption of these grasses has been low because most cultivars do not produce viable seeds and propagation is vegetative ${ }^{(4)}$.

Usually, pasture planting is made through the conventional planting methods and, mostly, though manual handling, which limits the efficiency of the process of pasture renovation due to the decrease in operational efficiency, raising the costs associated with pasture implementation through the planting of seedlings. Because of that, techniques with a higher degree of mechanization have been preferred, as a way to speed up the renovation process, reduce the workforce used in this activity and, with that, minimize the costs for the producer. The use of direct planting is an established method in agriculture, although it is absent in the livestock production systems, thus requiring the development of studies with different methods of soil management and more efficient techniques for establishment of pastures can increase the reliability of farmers and adoption rate in Brazil.

In the state of Acre, purple stargrass (Cynodon nlemfuensis cv. Lua) has been the most planted Cynodon cultivar, because of its productivity, aggressiveness and high tolerance to soil waterlogging ${ }^{(5)}$. This cultivar has formed productive, persistent and stable mixtures with forage peanut (Arachis pintoi cv. Belmonte), where beef cattle annual liveweight gains up to $850 \mathrm{~kg} \mathrm{ha}^{-1}$ have been measured ${ }^{(6)}$. Also, similar results were registered in Paraná state with the mixture of Cynodon spp. cv. Coastcross-1 with Arachis pintoi cv. Amarillo ${ }^{(7,8)}$. 
Thus, the objective of this study was to evaluate the technical and economic efficiency of vegetative propagation for establishment of mixed pastures of purple stargrass and forage peanut using two methods of soil management and two planting spacing.

The experiment was carried out in an area of 1.6 ha of degraded pasture of Brachiaria brizantha cv. Marandu in Senador Guiomard, State of Acre, Brazil (09 52'35"S, $67^{\circ} 25^{\prime} 16^{\prime \prime W}$ ), from November 2015 to March 2016. According to Köppen classification, the climate of the region is humid equatorial, with average annual rainfall of $1,958 \mathrm{~mm}$, with the rainy period from October to April and a well-defined dry season from June to August. The annual average temperature is $25.3{ }^{\circ} \mathrm{C}$ and the air relative humidity is approximately $85 \%{ }^{(9)}$.

The soil is classified as Red Yellow Latosol (Oxisol), with the following characteristics: $\mathrm{pH}\left(\mathrm{H}_{2} \mathrm{O}\right)=5.38 ; \mathrm{P}$ Mehlich-1=3.12 $\mathrm{mg} \mathrm{dm}^{-3} ; \mathrm{K}$ Mehlich-1=0,17 cmolc dm$^{-3} ; \mathrm{Ca}^{2+}=2.57$ cmolc dm ${ }^{-3} ; \mathrm{Mg}^{2+}=0.36$ cmolc dm${ }^{-3} ; \mathrm{H}+\mathrm{Al}=4.63 \mathrm{cmolc} \mathrm{dm}^{-3} ; \mathrm{CTC}=7.72 \mathrm{cmolc} \mathrm{dm}^{-3}$; organic matter $=10.35 \mathrm{~g} \mathrm{~kg}^{-1}$; base saturation $=40.1 \%$ and clay $=146.4 \mathrm{~g} \mathrm{~kg}^{-1}$.

The experimental design was in randomized blocks with four replications and treatments arranged in split-plot. The plots measured $40 \times 50 \mathrm{~m}$ and subplots $20 \times 50 \mathrm{~m}$. Two soil management methods were tested in plots: conventional tillage (CT), which consisted in vegetation desiccation with the herbicide glyphosate [(Roundup Ultra - Bayer) $(1.95 \mathrm{~kg}$ $\left.\mathrm{ha}^{-1}\right)$ ], followed by two passes of disc harrow and one of leveling disc harrow on the planting eve; and no-tillage (NT), in which the vegetation was subjected to sequential desiccation with 1.95 and $0.65 \mathrm{~kg} \mathrm{ha}^{-1}$ of glyphosate at 70 and $35 \mathrm{~d}$ before planting, respectively. Two planting spacing were tested in subplots: 50 and $100 \mathrm{~cm}$ between rows.

Stolons of purple stargrass (Cynodon nlemfuensis cv. BRS Lua) and forage peanut (Arachis pintoi cv. Belmonte) were harvested and prepared for planting by cutting stolon pieces with approximately $30 \mathrm{~cm}$ in length. The planting operation was carried out with a 3-row stolon planter coupled to a tractor. Grass stolons were planted in external rows and legume stolons in the central row.

At the time of no-tillage planting, surface residue of marandugrass presented water content of $460 \mathrm{~g} \mathrm{~kg}^{-1}$ and dry mass of $2,170 \mathrm{~kg} \mathrm{ha}^{-1}$. Planting spacing of $100 \mathrm{~cm}$ was obtained with a single planting operation, expending $700 \mathrm{~kg} \mathrm{ha}^{-1}$ of grass stolons and 300 $\mathrm{kg} \mathrm{ha}^{-1}$ of legume stolons. To reduce planting spacing to $50 \mathrm{~cm}$, a second planting operation was carried out interspersedly using consequently twice the amount of stolons.

Pastures were fertilized immediately after planting with $200 \mathrm{~kg} \mathrm{ha}^{-1}$ of NPK 8-28-16 and after $30 \mathrm{~d}$ with $100 \mathrm{~kg} \mathrm{ha}^{-1}$ of urea. Weeds were controlled with a pre-emergent application of herbicide trifluralin [(Trifluralina Nortox - Nortox S.A.) (1.8 kg a.i. ha ${ }^{-1}$ in NT and $0.81 \mathrm{~kg}$ a.i. ha ${ }^{-1}$ in CT)] and a post-emergent application of herbicide bentazon [(Basagran ${ }^{\circledR} 600$ - BASF S.A.) (1.5 kg a.i. ha $\left.\left.{ }^{-1}\right)\right] 30$ dalater. 
Shoot emergence of both forages was evaluated at $21 \mathrm{~d}$ after planting (DAP) by counting the number of sprouts inside a frame of $100 \times 100 \mathrm{~cm}$, in 15 sampling points per experimental unit. Pasture height, canopy cover and botanical composition were evaluated at 35, 56 and 84 DAP, in 12 sampling points per experimental unit using a frame of $100 \times 100 \mathrm{~cm}$. Within each sampling unit the following measurements were taken: pasture height $(\mathrm{cm})$, measured from ground level to the curvature of the plant canopy, using a ruler; canopy cover (\%), estimated visually; and botanical composition $(\%)$, visually estimating the percentage contribution of each component (purple stargrass, forage peanut, marandugrass and dicotyledonous and monocotyledonous weeds) to the total biomass ${ }^{(10)}$.

Herbage mass was evaluated at 84 DAP. Six samples were collected per experimental unit using a frame of $100 \times 100 \mathrm{~cm}$. The biomass was clipped to a $5-\mathrm{cm}$ stubble height, with subsequent weighing and drying at $55^{\circ} \mathrm{C}$ for $72 \mathrm{~h}$ in a forced air circulation oven (model TE-394/7, brand Tecnal-Brazil).

Relative levels of chlorophyll content in leaf blades of purple stargrass were measured at 70 DAP using a hand-held chlorophyll meter (model SPAD-502 Plus, brand Minolta Corporation, Japan). Readings were performed in the 15 first fully expanded leaf blades per experimental unit.

Technical coefficients and costs of services and inputs were appraised over the experiment for each modality of pasture renovation. The costs of mechanized services were calculated based on the total operating cost per hour worked of the tractorimplement set, using an electronic spreadsheet ${ }^{(11)}$. Input prices were collected in the market of Rio Branco, AC, in the first half of the year 2016.

Data were tested for normality of error (Shapiro-Wilk test) ${ }^{(12)}$ and homogeneity of variance (Bartlett's test) ${ }^{(13)}$. Percentage data concerning botanical composition and canopy cover were previously submitted to arcsine transformation. Data were submitted to analysis of variance using the PROC GLM of SAS ${ }^{(14)}$. Significant interactions $(P<0.05)$ were unfolded by using the 'SLICE' statement. Treatment means were calculated using the 'LSMEANS' statement ${ }^{(14)}$ and comparisons made using the $\mathrm{F}$ test $(P<0.05)$.

There was no effect $(P>0.05)$ of the soil management methods on shoot emergence of purple stargrass and forage peanut (Figure 1). However, both forages presented higher shoot emergence $(P<0.05)$ when planted with $50-\mathrm{cm}$ spacing. Pasture established by NT presented higher canopy cover $(P<0.05)$ at 84 DAP. Canopy cover over the experimental period was higher $(P<0.05)$ when pasture was planted with $50-\mathrm{cm}$ spacing, in particular at 35 DAP (Figure 2). 
Figure 1: Shoot emergence (number of sprouts $\mathrm{m}^{-2}$ ) of Cynodon nlemfuensis $\mathrm{cv}$. BRS Lua and Arachis pintoi cv. Belmonte at $21 \mathrm{~d}$ after planting according with soil management methods and planting spacing
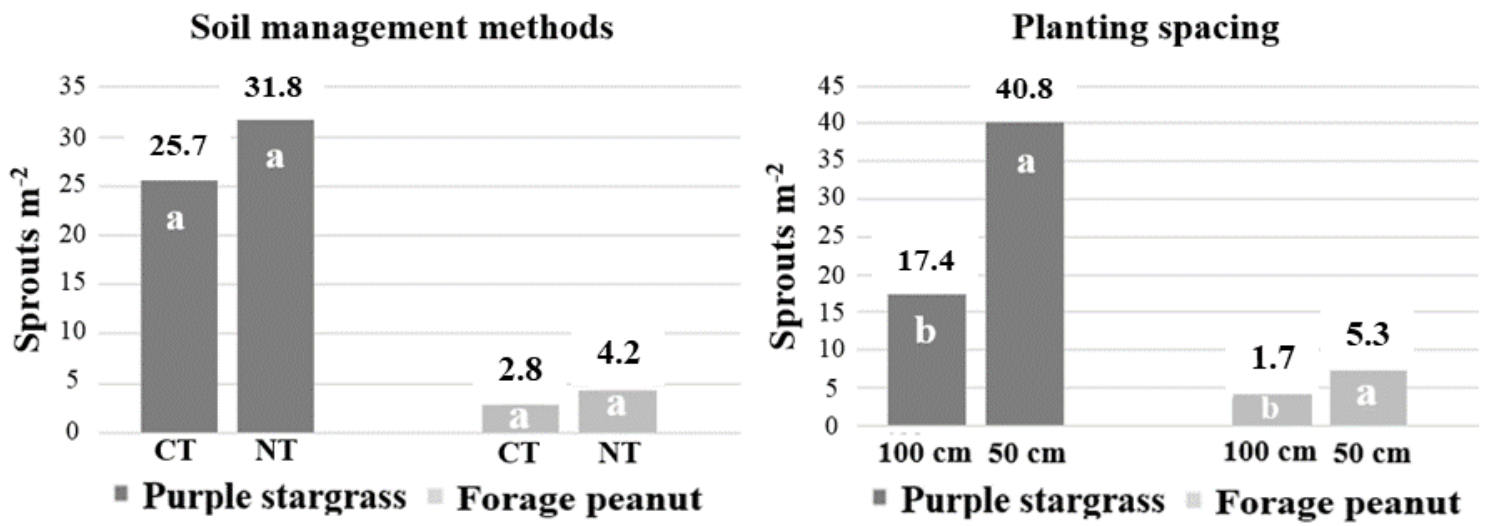

CT - conventional tillage; NT - no-tillage.

${ }^{\mathrm{ab}}$ Means followed by the same letters, for each forage and study variable, are not different $(P<0.05)$.

Figure 2: Evolution of canopy cover (\%) over the establishment period of Cynodon nlemfuensis cv. BRS Lua and Arachis pintoi cv. Belmonte as affected by the soil management methods and planting spacing
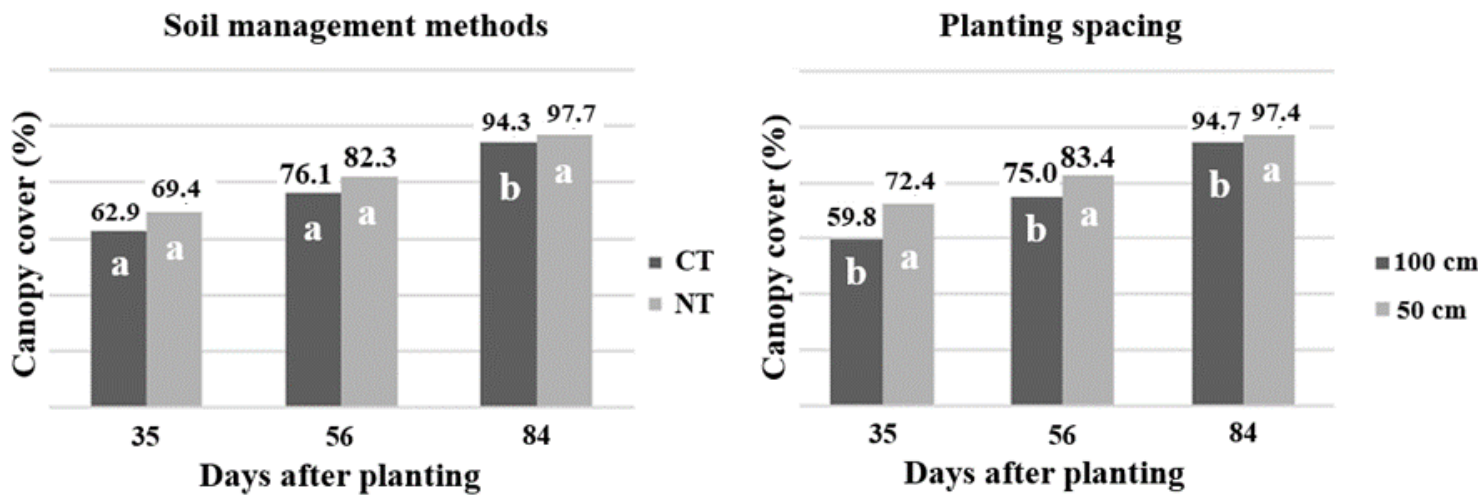

${ }^{\mathrm{ab}}$ Means followed by the same letters, for each date and study variable, are not different $(P<0.05)$.

Pasture height was higher $(P<0.05)$ in NT than in CT over the establishment period at 56 and 84 DAP and also was higher at 50-cm spacing at 56 DAP (Figure 3 ). 
Figure 3: Evolution of pasture height $(\mathrm{cm})$ over the establishment period of Cynodon nlemfuensis cv. BRS Lua and Arachis pintoi cv. Belmonte as affected by the soil management methods and planting spacing
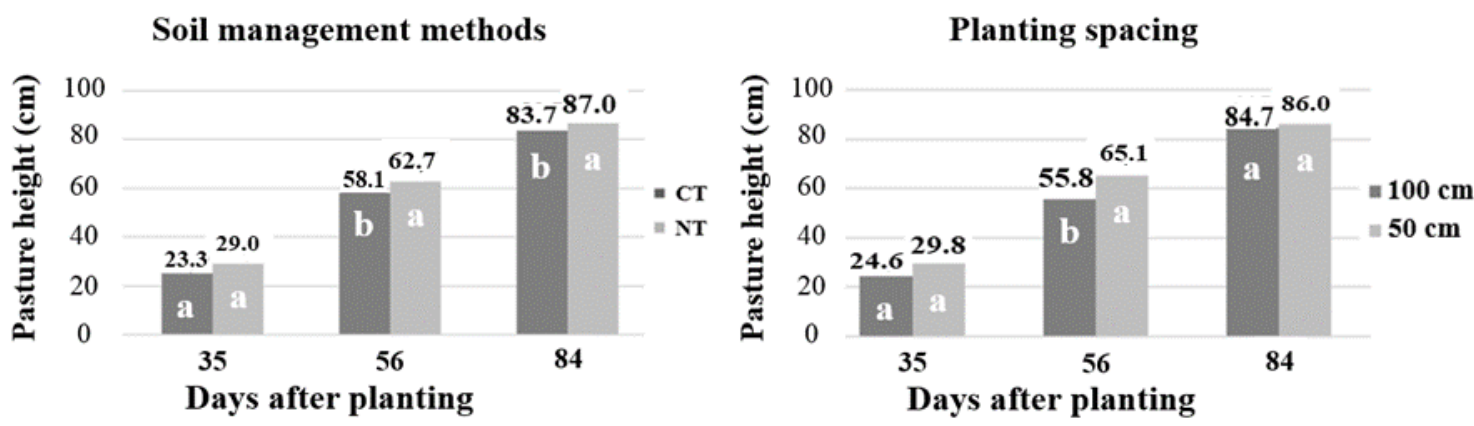

${ }^{a b}$ Means followed by the same letters, for each date and study variable, are not different $(P<0.05)$.

Botanical composition was monitored at 35, 56 and 84 DAP, and there was a significant interaction $(P<0.05$; Table 1$)$ between the soil management method and planting spacing only for the percentage of monocot-weeds at 56 DAP and purple stargrass at 84 DAP. Thus, such interactions will be unfolded in Table 2, after the presentation of the main effects in Table 1.

No-tillage contributed to greater $(P<0.05$; Table 1$)$ percentage of marandugrass at 35 DAP and also a higher $(P<0.05)$ percentage of monocot-weeds over the establishment period, although at 56 DAP the effect was only significant when associated to $100-\mathrm{cm}$ spacing (Table 2). When planted with CT, pastures presented higher percentage of purple stargrass at 56 DAP (Table 1).

Percentage of purple stargrass was greater $(P<0.05)$ over the establishment period when planting spacing was reduced from 100 to $50 \mathrm{~cm}$ (Table 1), although at 84 DAP this effect was significant only in NT (Table 2). Reducing planting spacing also increased $(P<0.05)$ the percentage of forage peanut at 84 DAP (Table 1). In contrast, the wider spacing favored the recruitment of marandugrass at 84 DAP and monocot-weeds at 35 DAP (Table 1), also at 56 DAP, when associated to NT (Table 2). 
Table 1: Influence of soil management methods and planting spacing on pasture botanical composition

\begin{tabular}{|c|c|c|c|c|c|}
\hline \multicolumn{5}{|c|}{ Botanical components (\%) } & \multirow{3}{*}{ SEM } \\
\hline \multirow[t]{2}{*}{ Component } & \multicolumn{2}{|c|}{$\begin{array}{l}\text { Soil management } \\
\text { methods }\end{array}$} & \multicolumn{2}{|c|}{$\begin{array}{l}\text { Planting spacing } \\
\text { (cm) }\end{array}$} & \\
\hline & $\overline{\mathrm{CT}}$ & NT & 100 & 50 & \\
\hline \multicolumn{6}{|l|}{35 days after planting } \\
\hline Cynodon nlemfuensis & $88.36 \mathrm{a}$ & $83.11 \mathrm{a}$ & $83.18 \mathrm{~b}$ & $88.28 \mathrm{a}$ & 2.159 \\
\hline Arachis pintoi & $3.54 \mathrm{a}$ & $4.09 \mathrm{a}$ & $3.59 \mathrm{a}$ & $4.04 \mathrm{a}$ & 0.586 \\
\hline Brachiaria brizantha & $2.00 \mathrm{~b}$ & $3.00 \mathrm{a}$ & $3.18 \mathrm{a}$ & $1.82 \mathrm{a}$ & 0.468 \\
\hline Dicot-weeds & $3.14 \mathrm{a}$ & $3.39 \mathrm{a}$ & $4.12 \mathrm{a}$ & $2.41 \mathrm{a}$ & 0.705 \\
\hline Monocot-weeds & $2.96 \mathrm{~b}$ & $6.42 \mathrm{a}$ & $5.93 \mathrm{a}$ & $3.45 \mathrm{~b}$ & 1.111 \\
\hline \multicolumn{6}{|l|}{56 days after planting } \\
\hline Cynodon nlemfuensis & $85.02 \mathrm{a}$ & $75.66 \mathrm{~b}$ & $77.08 \mathrm{~b}$ & $83.60 \mathrm{a}$ & 1.803 \\
\hline Arachis pintoi & $1.52 \mathrm{a}$ & $2.77 \mathrm{a}$ & $1.92 \mathrm{a}$ & $2.37 \mathrm{a}$ & 0.374 \\
\hline Brachiaria brizantha & $3.28 \mathrm{a}$ & $5.10 \mathrm{a}$ & $4.83 \mathrm{a}$ & $3.55 \mathrm{a}$ & 0.514 \\
\hline Dicot-weeds & $3.19 \mathrm{a}$ & $3.48 \mathrm{a}$ & $2.85 \mathrm{a}$ & $3.82 \mathrm{a}$ & 0.412 \\
\hline Monocot-weeds & - & - & - & - & - \\
\hline \multicolumn{6}{|l|}{84 days after planting } \\
\hline Cynodon nlemfuensis & - & - & - & - & - \\
\hline Arachis pintoi & $0.73 \mathrm{a}$ & $1.62 \mathrm{a}$ & $0.87 \mathrm{~b}$ & $1.47 \mathrm{a}$ & 0.190 \\
\hline Brachiaria brizantha & $4.77 \mathrm{a}$ & $7.19 \mathrm{a}$ & $8.31 \mathrm{a}$ & $3.65 \mathrm{~b}$ & 1.142 \\
\hline Dicot-weeds & $4.55 \mathrm{a}$ & $4.04 \mathrm{a}$ & $4.90 \mathrm{a}$ & $3.70 \mathrm{a}$ & 0.513 \\
\hline Monocot-weeds & $4.59 \mathrm{~b}$ & $8.42 \mathrm{a}$ & $8.69 \mathrm{a}$ & $4.33 \mathrm{a}$ & 1.075 \\
\hline
\end{tabular}

SEM - standard error of means; CT - conventional tillage; NT - no-tillage.

${ }^{a b}$ Means of each botanical component, followed by equal letters, are not different $(P<0.05)$.

Table 2: Effect of the interaction between the soil management methods and planting spacing

\begin{tabular}{|c|c|c|c|}
\hline \multicolumn{4}{|c|}{ Monocot-weeds at 56 DAP (\%) } \\
\hline \multirow{2}{*}{ Soil management methods } & \multicolumn{2}{|c|}{ Planting spacing } & \multirow{2}{*}{ SEM } \\
\hline & $100 \mathrm{~cm}$ & $50 \mathrm{~cm}$ & \\
\hline Conventional tillage & $8.6 \mathrm{Ba}$ & $5.3 \mathrm{Aa}$ & \multirow{2}{*}{1.2817} \\
\hline No-tillage & $18.0 \mathrm{Aa}$ & $8.0 \mathrm{Ab}$ & \\
\hline \multicolumn{3}{|c|}{ Cynodon nlemfuensis cv. BRS Lua at 84 DAP (\%) } & \multirow{2}{*}{ SEM } \\
\hline \multirow{2}{*}{ Soil management methods } & Planting & & \\
\hline & $100 \mathrm{~cm}$ & $50 \mathrm{~cm}$ & \\
\hline Conventional tillage & $82.7 \mathrm{Aa}$ & $88.0 \mathrm{Aa}$ & \multirow{2}{*}{2.1477} \\
\hline No-tillage & $69.0 \mathrm{Bb}$ & $85.7 \mathrm{Aa}$ & \\
\hline
\end{tabular}

SEM - standard error of means.

Means followed by the same letters, uppercase in columns and lowercase in lines, are not different $(P<0.05)$. 
There was no interaction $(P>0.05)$ between the soil management method and planting spacing for herbage mass at 84 DAP, with significant effect $(P<0.05)$ only for planting spacing (Table 3 ). Pasture productivity was $20 \%$ higher when planted at $50-\mathrm{cm}$ spacing. There was an interaction between soil management method and planting spacing on the relative levels of chlorophyll (SPAD values) in leaves of purple stargrass, as a lower SPAD value was measured on NT with100-cm spacing (Table 4).

Table 3: Effect of soil management method and planting spacing on HM - herbage mass (Cynodon nlemfuensis cv. BRS Lua and Arachis pintoi cv. Belmonte) at $84 \mathrm{~d}$ after planting

\begin{tabular}{|c|c|c|c|c|c|}
\hline \multirow{2}{*}{ Variable } & \multicolumn{2}{|c|}{ Soil management methods } & \multicolumn{3}{|c|}{ Planting spacing $(\mathrm{cm})$ SEM } \\
\hline & $\overline{\mathrm{CT}}$ & NT & 100 & 50 & \\
\hline $\mathrm{HM}\left(\mathrm{kg} \mathrm{ha}^{-1}\right)$ & $4,960 \mathrm{a}$ & $5,259 \mathrm{a}$ & $4,634 \mathrm{~b}$ & $5,585 \mathrm{a}$ & \\
\hline
\end{tabular}

SEM - standard error of means; CT - conventional tillage; NT - no-tillage.

${ }^{\mathrm{ab}}$ Means followed by the same letters in lines, for each study variable, are not different $(P<0.05)$.

Table 4: SPAD values on leaf blades of Cynodon nlemfuensis cv. BRS Lua at $70 \mathrm{~d}$ after planting

\begin{tabular}{llll}
\hline \multirow{2}{*}{ Soil management methods } & \multicolumn{2}{l}{ Planting spacing $(\mathbf{c m})$} & \multirow{2}{*}{ SEM } \\
\cline { 2 - 3 } & 100 & 50 & \\
\hline Conventional tillage & $29.7 \mathrm{Aa}$ & $29.7 \mathrm{Aa}$ & 0.2156 \\
No-tillage & $28.1 \mathrm{Bb}$ & $29.1 \mathrm{Aa}$ & \\
\hline
\end{tabular}

SEM - standard error of means.

Means followed by equal letters, uppercase in lines and lowercase in columns, are not different $(P<0.05)$.

In practical terms, the method of soil management had relatively little influence on pasture establishment performance, which was adequate in both methods, as canopy cover exceeded $94 \%$ at 84 DAP. However, NT positively influenced pasture height and canopy cover at the end of the establishment period. This effect seems to be related with a best sprouting of stolons after planting. In NT, the effect of residues on the soil surface can decreases temperature and water loss through evaporation, thereby reducing dehydration and increase plants survival after planting as demonstrated by Gasparim et $a l^{(15)}$ and Furlani et $a l^{(16)}$. Moreover, it was observed that in NT were opened shallower furrows and buried a lower proportion of stolons, due to a firmer soil structure. In a study with Tifton 85 bermudagrass (Cynodon spp.), partial burial of stolons improved sprouting percentage when compared to total burial ${ }^{(17)}$.

Reducing planting spacing from $100 \mathrm{~cm}$ to $50 \mathrm{~cm}$, with use of twice the amount of stolons, more than doubled shoot emergence of purple stargrass and forage peanut and speed up canopy cover until 56 DAP. However, the difference in canopy cover disappeared at the end of establishment period. 
In degraded Brachiaria pastures, a big and active seed bank and the aggressiveness of its seedlings, hampers their replacement by other forages ${ }^{(18)}$. The weed control protocol used in this study was effective in reducing the recruitment of marandugrass and. Previous desiccation with glyphosate in CT and sequential desiccation in NT, associated with the use of herbicide trifluralin, concurred to prevent the regrowth of marandugrass and the emergence of its seeds. As a result, botanical composition measured at 84 DAP showed only 4 to $8 \%$ of marandugrass. Conventional tillage, which associated mechanical and chemical methods of weed control, was more effective in controlling marandugrass and monocot-weeds (mainly Cyperaceae), when compared to NT, where only chemical methods were used. Disc-harrowing contributes to bury weed seeds, reducing their infestation potential. In NT, the residues on the soil surface also contributes to reduce weed emergence. However, higher emergence of weeds was observed along the furrows where soil mobilization occurred and residue was buried.

The herbicide trifluralin can be retained by residues, even when rain occur soon after application $^{(19)}$, reducing its efficacy. However, the formulation used in this study is registered for NT and CT, with higher dose for NT to compensate for retention by surface residues.

Reducing planting spacing from $100 \mathrm{~cm}$ to $50 \mathrm{~cm}$ decreased marandugrass and monocotweeds incidence. Herbicide bentazon reduced the incidence of dicot-weeds in all treatments, and the main species found was Calopogonium mucunoides, a forage legume of spontaneous occurrence in the area ${ }^{(20)}$.

At the end of the establishment period, purple stargrass represented more than $80 \%$ of the botanical composition in all treatments, except in NT with 100-cm spacing, which favored infestation by sedges. Forage peanut participation in botanical composition was small, decreasing from approximately $3.8 \%$ on average at 35 DAP to $1.2 \%$ at 84 DAP. This can be attributed to the highest planting rate of purple stargrass in relation to forage peanut $(2: 1)$, the lowest sprouting efficiency of forage peanut stolons, the faster establishment of purple stargrass and also the effect of nitrogen $(\mathrm{N})$ fertilization at 30 DAP, which favors grass competition against the legume. At 21 DAP, the ratio of grass shoots to legume shoots was 7.5:1 in 50-cm spacing and 10:1 in 100-cm spacing. This indicates that the sprouting efficiency of purple stargrass was three to five times higher than that of forage peanut.

Only mature stolons were used for both plants. Thus, this difference in sprouting efficiency can be inherent to these plants, but also related to the degree to which planting material is buried in the soil at planting. As previously mentioned, complete burial of stolons reduces sprouting efficiency. It was noted a greater proportion of forage peanut stolons completely buried than that of purple stargrass. Forage peanut was planted in the central row and, as the stolon planter has no independent lines, there may have been a further deepening of the central furrows. Stolon preparation may also have influenced, as 
forage peanut stolons were cut shorter than purple stargrass ones. These aspects deserve further investigations.

This would also match the stolon planting rate (1:1). Even so, there should be initial predominance of grass because of its faster establishment. Slowing purple stargrass establishment to reduce its competition against forage peanut can have negative consequence on weed control ${ }^{(21)}$. Thus, it could be preferable to accept a lower initial proportion of legume than a pasture infested by hard to control weeds. This mixture has shown high compatibility in Acre. Dominance of one species tends to be temporary, with proportion often stabilizing with time in one-third forage peanut and two-thirds purple stargrass $^{(5)}$.

Start the first grazing when canopy cover reaches $80 \%$ instead of $100 \%$ as occurred in this study, could also decrease initial grass competitiveness without compromising weed control. In addition, top-dressing $\mathrm{N}$-fertilization should only be used under NT, as $\mathrm{N}$ release from soil organic matter is higher under $\mathrm{CT}^{(22)}$.

The relative content of chlorophyll (SPAD value) on plant leaves has been used to infer the $\mathrm{N}$ status of plants ${ }^{(23)}$. In this study, greater SPAD values in purple stargrass were expected in CT, due to the effect of soil tillage and incorporation of marandugrass residues, which could stimulate the decomposition of organic matter and $\mathrm{N}$ release in relation to NT. However, lower SPAD values were observed only when stargrass was planted in NT with 100-cm spacing. This may indicate increased competition for $\mathrm{N}$ with monocot-weeds in this treatment. $\mathrm{N}$-fertilization $\left(45 \mathrm{~kg} \mathrm{~N} \mathrm{ha}^{-1}\right)$ also contributed to reduce the differences among the treatments.

Novel pasture establishment methods should be judged based on its technical and economic efficiency. No-tillage requires greater investment in inputs but saves on services, in particular those related to tillage operations in CT (Table 5). In general, NT saves the equivalent to 15 kilograms of beef cattle per hectare compared to CT. Reducing planting spacing from $100 \mathrm{~cm}$ to $50 \mathrm{~cm}$ increases the cost of pasture renovation in more than $30 \%$, due to increased expenses with harvesting, transporting, and planting stolons. 
Table 5: Cost estimate to establish a mixed pasture with Cynodon nlemfuensis cv. BRS Lua and Arachis pintoi cv. Belmonte, according to the method of soil management and planting spacing

\begin{tabular}{lccccc}
\hline & \multicolumn{2}{c}{ Conventional tillage } & & \multicolumn{2}{c}{ No-tillage } \\
\cline { 2 - 3 } Cost per ha & \multicolumn{2}{c}{ Planting spacing $(\mathbf{c m})$} & & \multicolumn{2}{c}{ Planting spacing $(\mathbf{c m})$} \\
\cline { 2 - 3 } \cline { 5 - 6 } & 100 & 50 & & 100 & 50 \\
\hline Services, $\mathrm{R} \$$ & 847.21 & $1,260.00$ & & 530.28 & 943.06 \\
Inputs, $\mathrm{R} \$$ & 614.00 & 660.00 & & 817.00 & 863.00 \\
Total, $\mathrm{R} \$$ & $1,461.21$ & $1,920.00$ & & $1,347.28$ & $1,806.06$ \\
Total, $\mathrm{kg}^{1}$ & 180.0 & 235.5 & & 165.0 & 222.0 \\
\hline
\end{tabular}

${ }^{1}$ Total cost estimate in arroba $(\mathrm{kg})$ of beef cattle, quoted in $\mathrm{R} \$ 8.13$ in March 2016 in Rio Branco, AC. Source: Andrade et al(2016).

The cheapest method (NT with 100-cm spacing) had the smallest technical efficiency, allowing greater recolonization of marandugrass and monocot-weeds. The total investment for pasture renovation planting a mixture of purple stargrass and forage peanut, converted into 15 kilograms of beef cattle, ranged from 165 to 240 kilograms per hectare. These methods are more expensive than establishing pastures using grass seeds in Acre, which historically have varied from 120 to 180 kilograms per hectare ${ }^{(24)}$.

Degraded Brachiaria brizantha pastures can be renovated by planting a mixture of purple stargrass and forage peanut with both CT and NT. In NT, planting 2,000 kg ha-1 of stolons in 50-cm spacing speed up pasture establishment and increases weed control effectiveness. Reducing row spacing from $100 \mathrm{~cm}$ to $50 \mathrm{~cm}$ increases the cost of pasture renovation in more than $30 \%$. The use of two parts of purple stargrass for one part of forage peanut do not assure the legume establishment, leading to an early predominance of the grass. Forage peanut is slower to establish than purple stargrass. Greater planting rates of forage peanut and anticipation of first grazing are techniques that should be tested to reduce initial grass dominance.

\section{Acknowledgments}

Thanks to the CAPES and CNPq development agencies for granting the scholarship, and the owner of Iquiri Farm, Joaquim Pedro Ribeiro do Valle Filho.

The authors declare they have no conflict of interest regarding the work presented in this report. 


\section{Literature cited:}

1. Valle CB, Simeão RM, Barrios SCL. Seleção e melhoramento de plantas forrageiras. In: Reis RA, Bernardes TF, Siqueira GR. Forragicultura: ciência, tecnologia e gestão dos recursos forrageiros. 1rst ed. Jaboticabal: M. de L. Brandel-ME; 2013:349-366.

2. Pedreira BC, Pitta RM, Andrade CMS, Dias-Filho MB. Degradação de pastagens de Braquiarão (Brachiaria brizantha cv. Marandu) no Estado de Mato Grosso. 1rst ed. Sinop (MT): Embrapa Agrossilvipastoril; 2014.

3. Aronovich S, Rocha GL. Gramíneas e leguminosas forrageiras de importância no Brasil Central Pecuário. Inf Agropec 1985;11(132):3-13.

4. Pedreira CGS. Gênero Cynodon. In: Fonseca DM, Martuscello JA. Plantas forrageiras. 1rst ed. Viçosa: UFV;2010:78-130.

5. Andrade CMS, Assis GML, Fazolin M, Gonçalves RC, Sales MFL, Valentim JF, Estrela JLV. Grama-estrela-roxa: gramínea forrageira para diversificação de pastagens no Acre. 1rst ed. Rio Branco (AC): Embrapa Acre; 2009.

6. Andrade CMS, Ferreira AS, Casagrande DR. Uso de leguminosas em pastagens: potencial para consórcio compatível com gramíneas tropicais e necessidades de manejo de pastejo [Anais]. Simpósio sobre Manejo de Pastagem. Piracicaba, SP. 2015:27.

7. Paris W, Cecato U, Branco AF, Barbero LM, Galbeiro S. Produção de novilhas de corte em pastagem de Coastcross-1 consorciada com Arachis pintoi com e sem adubação nitrogenada. Rev Bras Zootec 2009;38(1):122-129.

8. Barbero LM, Cecato U, Lugão SMB, Gomes JAN, Limão VA, Abrahão JJS, Roma CFC. Produção animal e valor nutritivo da forragem de pastagem de coastcross consorciada com amendoim forrageiro. Arq Bras Med Vet Zootec 2010;62(3):645653.

9. Duarte AF. Aspectos da climatologia do Acre, Brasil, com base no intervalo 19712000. Rev Bras Meteorol 2006;21(3b):308-317.

10. Whalley RDB, Hardy MB. Measuring botanical composition of grasslands. In: t'Mannetje L, Jones RM. Field and laboratory methods for grassland and animal production research. 1rst ed. Londres: CABI Publishing; 2000:67-102. 
11. CATI - Coordenadoria de Assistência Técnica Integral. Estimativa do custo operacional de tratores agrícolas. São Paulo: CATI. 2016. http://www.cati.sp.gov.br/portal/produtos-e-servicos/publicacoes/acervotecnico/acervo/administracao_rural/custo_operacional_maquinas.xlt. Access June 29, 2016.

12. Shapiro SS, Wilk MB. An analysis of variance test for normality (complete samples). Biometrika 1965;52(3/4):591-611.

13. Bartlett MS. Tests of significance in factor analysis. Br J Stat Psychol 1950;3(2):7785.

14. SAS - Statistical Analysis System, SAS Institute Inc., SAS User's Guide, Cary, USA: SAS Institute Inc.; 2003.

15. Gasparim E, Ricieri RP, Silva SDL, Dallacort R, Gnoatto E. Temperatura no perfil do solo utilizando duas densidades de cobertura e solo nu. Acta Sci Agron 2005;27(1):107-115.

16. Furlani CEA, Gamero CA, Levien R, Silva RPD, Cortez JW. Temperatura do solo em função do preparo do solo e do manejo da cobertura de inverno. Rev Bras Ciênc Solo 2008;32(1):375-380.

17. Baseggio M, Newman YC, Sollenberger LE, Fraisse C, Obreza T. Stolon type and soil burial effects on 'tifton $85^{\prime}$ ' bermudagrass establishment. Crop Sci 2014;54(5):2386-2393.

18. Rodrigues LRA, Rodrigues TJD. Estabelecimento dos capins do gênero Cynodon em áreas de Brachiaria spp [Anais]. Workshop sobre o Potencial Forrageiro do Gênero Cynodon. Juiz de Fora, MG. 1996:1.

19. Rodrigues BN, Lima J, Yada IFU, Fornarolli DA. Influência da cobertura morta no comportamento do herbicida trifluralin. Planta Daninha 1998;16(2):163-173.

20. Valentim JF, Carneiro JC. Pueraria phaseoloides e Calopogonium mucunoides [Anais]. Simpósio sobre Manejo de Pastagem. Piracicaba, SP. 2000:17.

21. Miranda EM, Saggin Jr OJ, Silva EMR. Amendoim forrageiro: importância, usos e manejo. 1rst ed. Seropédica (RJ): Embrapa Agrobiologia; 2008.

22. Borghi E, Crusciol CAC. Produtividade de milho, espaçamento e modalidade de consorciação com Brachiaria brizantha em sistema plantio direto. Pesq Agropec Bras 2007;42(2):163-171. 
23. Guimarães SL, Santos CSA, Silva EMB, Polizel AC, Batista ÉR. Nutritional characteristics of marandu grass (Brachiaria brizantha $\mathrm{cv}$. marandu) subjected to inoculation with associative diazotrophic bacteria. Afr $\mathrm{J}$ Microbiol Res 2016;10(24):873-882.

24. Andrade CMS, Santos DM, Ferreira AS, Valentim JF. Técnicas de plantio mecanizado de forrageiras estoloníferas por mudas. 1rst ed. Rio Branco (AC): Embrapa Acre; 2016. 